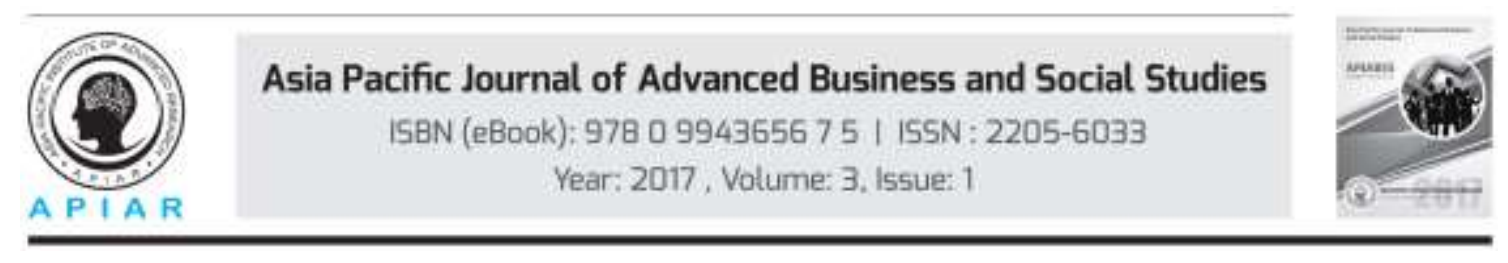

\title{
OPTIMIZATION OF SOCIAL CAPITAL ON MANAGEMENT OF ECOTOURISM'S INFRASTRUCTURE
}

\author{
Ahmad Ma'ruf \\ Universitas Muhammadiyah Yogyakarta, Indonesia \\ email: macrov_jogja@yahoo.com
}

\begin{abstract}
Poverty in villages or rural areas is still high, including in Indonesia. A Variety of creativity from citizens or outside the parties, such as government and nongovernmental organizations (NGOs) has efforts to reduce destitution by optimizing the potential of the area. One sample of that is developed ecotourism by creating Tourist Village, as is done by the Candran village, Imogiri, Yogyakarta which was introduced by citizens as the International Tourist Village.

As a tourist village, the village requires basic infrastructure adequacy. In terms of basic infrastructure's management (provisioning and superintend), there are social assets in the form of social capital that can be developed so that development activities are implicated in increasing village's revenue. The process of social capital development can implicate in a participation way through PRA approach and for analyzing using analytical approach SOAR (Strengths, Opportunities, Aspirations, and Results). This research succeeded in formulating the efforts of citizens keeping and procurement infrastructure through the optimization social capital that developing in the Candran International Tourist Village.
\end{abstract}

Keywords: Social Capital, Ecotourism, SOAR, and Infrastructure Management.

\section{Background}

Every country, particularly the poor and developing countries, including Indonesia, collective with an international institutions have agreed on eight goals of development which are embraced in the MDGs, including poverty reduction and sustainable environmental construction. Until 2012, there appears to be success in achieving the poverty decrease targets but the rate is varied between countries (United Nations, 2012).

Spatially, poverty in villages or rural areas is still high in Indonesia. Variety of creativities from citizens or from outside the parties, such as government and non-governmental organizations (NGOs) make serious effort to reduce poverty by optimizing the potential of the area. One example of that is to develop ecotourism by creating Tourist Village, as is done by the Candran village, Imogiri, Yogyakarta which was introduced by citizens as the International Tourist Village.

Candran village historically existed since the time of Sultan Agung I around 1635 BC. The name of this village, Candran, is derived from the name of Mbah Condro. He is a red brick maker for the graves of the kings from Imogiri. Candran village location is in Imogiri, the west site of cultural graves of the kings of Mataram Yogyakarta and 
Surakarta. The number of citizens in this village is 1539 person in 315 family heads. Majority of the citizens has a job as a micro-scale farmers and food artisans such as tempe, emping melinjo, and food market, with average revenue of Rp.300.000 permonth.

Although majority of citizens have low-income, they have harmonious lives. Many potential can be developed to increase citizen's income. In 1998, Kristiya Bintoro, the figure in this village, took the initiative to establish 'Museum Tani Jawa' or Java Farmers Museum and developing this village as a tourist destination with special interest in ecotourism category. The main motivation is to bequeath to young people about the values of farmer struggle, especially rice farmers, also as learning tool for breeding ducks and cows. In 2012, from January to December, there were 22.314 tourists, which consisted of 21.344 domestic tourists and 970 foreigners.

The Carrying capacity of the existing infrastructure in the Candran village today include a paved road with a width of 4 meters and a length of 300 meters around the village Candran. In addition, to support agriculture as natural tourism objects has been built permanent technical irrigation along the $1.5 \mathrm{~km}$ with good condition. Associated with lighting, this village has been given electricity from PT PLN, whereas for water sourced from wells.

Meanwhile, the social activities of citizens in this village is actively ongoing, such as regular meetings of citizens, roving patrols every night, citizens recitations, village clean mutual assistance, and many others social activities. For cultural events as part of the existing tourist attractions include art music "gejog lesung", "nini thowong", farm boy percussion, and "gejog lesung" combined with gamelan. The process of development is being through participation in certain events.

Social capital is defined as those aspects of the structure of individual's relationships enable them to create new values. This concept is further elaborated the issues related to the construction of community economic participatory, and political. The capital can be called of social capital when it contains three main components. i.e., 1) the ability to crafting institution; 2) the presence of equal participation and fair, and 3) the existence of mutual trust (Coleman, 1988; Narayan, 1999).

The essential of social capital is a social relationship that exists in the daily life of the community. Social relations are reflecting social interaction results in a relatively long time to create network, patterns of cooperation, social exchange, mutual trust, including values and norms underlying social relations (Ibrahim, 2006).

Social capital will not separate from the three main elements, they are: (a) Trust (honesty, fairness, egalitarian attitudes, tolerance, and generosity), (b) Social Networks (participation, reciprocity, solidarity, cooperation), (c) Norms (shared values, norms and sanctions, the rules). Pierre Bourdieu (Field, 2005) explains that the main focus of social capital is the definition of "social level". He said that the social capital associated with other capitals, such as economic capital and cultural capital. Those three capitals will work effectively if all of them have a relationship.

There is a relationship between social capital to the process of sustainable development, including in the form of ecotourism, and infrastructure development. Sustainable development aimed at reducing poverty require complementary policies, from the pattern of participation, conflict reduction, reduction of corruption, and efforts to increase investment in infrastructure (Ogujiuba \& Jumare, 2012). Sustainable 
development may be realized through appropriate (linkages) between the natural, socioeconomic aspects, and culture.

Budimanta (2005) states that sustainable development is a way of viewing the activities carried out in a systematic and planned within the framework of improving the wellbeing, quality of life and environment of human beings without reducing access and opportunity for future generations to enjoy and use.

According to Hudson (1997), the success and progress of communities has affected by the availability of physical infrastructure for the distribution of resources and public services. The quality and efficiency of infrastructure affects the quality of life, social systems, and the sustainability of economic and business activities.

According to D'Auria (2009) furthering the development of cultural tourism is strongly linked with the maintenance of historic buildings. In this case, Kutzner, Wright and Stark (2009) assert that the industry development of a sustainable tourism requires a thorough understanding of the interests of the tourists. In addition, there needs to be clarity and a sense of control mechanism in the development of tourism to minimize the negative impact of tourism to communities.

The accurate above background, and need for planning, procurement, and maintenance of the infrastructure to support the development of the Candran village to be tourist village, then there are some issues proposed in this study, they are: 1) what are the social capital developing in the community that the Candran village can be optimized to support infrastructure management as a tourist village? And 2) how to formulate the optimization strategy of social capital to support infrastructure management as a tourist village?

The aim of this study is to explore the formulation of social capital development strategies, to optimize the provision and management of community based infrastructure that can support the development of tourist village in order to increase the income of citizens.

\section{Methodology}

This study used a qualitative research approach. The process is extracting the problem and formulating a plan of action using the PRA (Participatory Rural Appraisal) and SOAR Analysis. In this research, the PRA method used is the technique of Focus Group Discussion (GFD) and search location that PRA techniques for direct observation of community resources and the environment, by walking through the village to follow a certain trajectory agreed.

Meanwhile, to formulate the development strategies of social capital in the tourist village infrastructure management used SOAR analysis (Strengths, Opportunities, Aspirations, Results) analysis using an Appreciative Inquiry (AI) approach that focuses on identifying and building strengths rather than weaknesses and the opportunities and threats.

SOAR analysis stage in the research began with an inquiry that uses positive questions to learn the core values, vision, strength, and potential opportunities. In this phase, the perspective of every citizen a key figure appreciated. This is also being order to fully understand the values held by the members of the community and the best thing that ever happened in the past. Then the perpetrators of the tourist village brought into the imagination phase, use the time to dream and designing future expected. In this phase, reinforced values, vision and mission are created. Long-term goals and strategic alternatives and recommendations formulated. The third phase of innovation, the 
beginning of the design goals of short-term, tactical and functional plans, programs, systems and structures are integrated to achieve the expected future goals (in this case discusses the tourist village infrastructure). In order to achieve the best results that are measurable, the people who participate in the process should be provided inspiration through a system of recognition and awards.

The scope of this study is to identify the social capital associated with the management infrastructure that supports the development of rural tourism. The type of infrastructure that rural tourism is the subject of discussion the main road, village roads, village trails, water supply, drainage, dams, irrigation, sewage treatment, telecommunications networks, and electricity.

\section{Analysis and Study}

\section{Social Infrastructure and Capital Adequacy}

As a tourist village, it would require the availability of good infrastructure. Based on the results of the Focus Group Discussion and search locations. These methods are part of the PRA then found some information infrastructure conditions in the Candran village. It is still perceived by the public is still not sufficient, among others, are: there is no disposal and processing of garbage non-organic; bus impossible to enter the village, because the roads on this village is not good enough; there is no specific parking area. During this time for buses parked alongside a road; been no community center; no telephone network cabling, and no toilets that meet the standards (international standards), including the location of the homestay. In addition, the village is also no specific markers as a tourist village.

In the FGD process has explored various forms of social capital that exist in the people of Candran village and potentially optimized to support infrastructure management as a tourist village. In social life, evolving and maintained are traditional culture. Patterns of social interaction that mutual respect and help each other (togetherness) are well preserved.

People in the Candran village actively participate in various public activities such as clean village, as well as special events such as the celebration of "mantu", celebrate the day to be grateful for thanksgiving or on sorrow conditions "layatan". High solidarity seemly of the average citizen spending for social activities between Rp250.000-Rp.400.000 per month, or about 30 percent of total household expenditures. Sizeable numbers is understood as a social investment. It is based on that one day the family will also pay social gain from the neighbors when the citizens have or there is a celebration and grief.

In order to maintain the reliability of existing infrastructure in the village, the village leaders coordinated routine and non-routine mutual aid. This routine is to clean and care for village roads and irrigation fields. At a certain moment, such as in August, they are carried to the wider until citizen's yard, and at the beginning Ramadhan, there is activities to clean a whole village and mosque.

The collaboration process did by an adult people on that village. There is a structured division of labor, whereby the men to do the cleanup work, hoeing, and do building work, while for women to prepare traditional foods and beverages/snacks, sweeping the yard and street. This reflects the participatory process carried out not only by men or only by women, but together.

For some people who cannot come to do service projects (togetherness), then they will donating drinks and snacks voluntarily. The other people do not give social sanction to 
the some people who did not participate in the social activities of the village. This confirms the form of tolerance and understanding of differences in participation that arise not because of laziness but because of work demands.

\section{Strategies for Optimization of Social Capital}

Through the limited FGD process in Java Farmers Museum, the obtained data was systematically excavated and explored as the analysis stage of SOAR. At the exploration stage, there are some positive questions posed to citizens in relation to management of village infrastructure, inter alia:

a. What infrastructure is necessary to support the tourist village?

b. How do procurement, construction and maintenance of facilities and infrastructure that already exist or are to be built?

c. What are the infrastructure needs that would met tourist villages by the community?

d. What are the social power of the citizens to meet the needs of the supporting infrastructure of the tourist village outright can enjoy people in daily life?

After a few questions answered and be discussed outright of FGD, then the researcher facilitates the imagination of a forum to build a description of the village if the various facilities and infrastructure needs are met. The description results imagination includes: visitors, especially foreign tourists will be more likely to visit and have a positive impression has lived in the Candran village. This visit is believed to augment their income, because the average citizen will receive income from the rental homstey of Rp.150.000-Rp.200.000 per day, get an extra Rp.100.000 from the train make traditional "tempe' and pounding melinjo. Similarly, there are five young men who became tour guides will receive about Rp.150.00o per day working as a tour guide.

The results of the meta imagination plan that has been formulated together into a "dream" these villagers, and conducted exploration in the form of stage innovations into the third phase of the analysis SOAR. This process is facilitated by a researcher in the discussion forum. In summary, the analysis results of SOAR, inter alia:

To meet the financing needs of the care and development of infrastructure to support tourism village is being through the process of defining the social contributions made by citizens meetings, as well as through contributions in the form of "jimpitan" money rounds. It also proactively submitted a proposal to the government, as well as citizens who have business activities and production are deemed to have sufficient income. The term is used in the process of collecting forum on citizens called "serkileran", while the proposals on local government proposals in the form of social.

The process of implementation of the activities carried out in mutual help, no one is paid. For those who are not forced to be present in the mutual assistance is expected to help provide snacks and drinks. It was agreed by the manager of Tani Jawa Museum where the museum is a museum belonging to residents who have given land and buildings for museum and tourist attractions, superintendent numbering 4 people who all residents of this village, will continue to hold events. Some examples are the "Memedi Sawah" Festival (repellent forms that sparrows do not eat rice) and "Ngliwet" Festival (traditional cooking rice). All activities will invite various local and national leaders that Candran village will be known again by tourists, especially foreign tourists who want special interest. 
Maintaining social activities, such as regular meetings of each group of people, RT basis, arisan groups, etc, to discuss together about all things related to the development and village activities, including the activities of the management of rural infrastructure that supports tourism activities. In addition, it will also continue the tradition of natural farming, other than as an object of special interest, it is also believed to be more environmentally friendly. Activities such as plowing fields with water buffalo, women together "Tandur " planting rice, coconut tree climbing to take "degan" young coconut, soybean tempe made by wrapping the leaves and ropes, as well as make a variety of crafts markets snack foods will be maintained as efforts to preserve the local culture as well as a wealth of objects leading foreign tourists. There is a spirit of managing Java Farmers Museum seeks to attempt to gain an appreciation of the local government, government, and tourism organizations so that there is a pride for all residents of the Candran village.

\section{Conclusion and Recommendations}

Based on the SOAR analysis, conclusions can be formulated as follows:

1. Some forms of social capital such as mutual respect, mutual aid, self-reliance, and tolerance in a society that is still growing at a Candran village has the potential to be optimized in order to take care of existing rural infrastructure, even doing selfhelp for the provision of facilities and infrastructure that are material could be reached by the citizens, standards such as public toilets, tourist village gate marker, and community centers. As for needs that are beyond the capacity of citizens, such as telephone cable network will be delivered to the other party (government and PT Telkom).

2. The process of imagination residents woke up because there is hope of getting increased revenues from tourism activities that will grow in the village as the tourst village special interest. Activities of plowing, etc. become the most sought after attraction of foreign tourists..

3. Strategies to optimize social capital through formal forum in the form of regular meetings of the hamlet residents which is the medium of communication between village residents. In addition, social capital actualized in joint activities on a regular basis, such as community service routine, patrolling, dues citizens through "jimpitan" money collected patrol officers. In addition, the involvement of citizens in all the activities of tourists visiting the Candran village will provide economic benefits concerning maintaining the tourism village, including the procurement and maintenance of rural infrastructure.

Suggestions for further research and development are:

1. For the local goverment, specifically the Department of Public Works need regular supervision feasibility of existing infrastructure in the Candran village thus supporting activities as a tourist village.

2. Local government need competition even for infrastructure management at local, regional, and national levels to appreciate the citizen participation process that builds self-reliance in the provision and maintenance of rural infrastructure, particularly in the tourist village.

3. This study needs to be formula that a more structured model of empowerment that social capital is able to be optimized and maintained as an asset of rural development, as developed in the Candran village. 


\section{References}

i. Budimanta, A.,Raharjo, D. Y. \& Rosdiana, E., 2005. Environmental LeadershipSeri Kajian Sustainable Future. Penerbit Indonesia Center for Sustainable Development.

ii. D'Auria, A., 2009. Urban Cultural Tourism: Creative Approaches for Heritage-Based Sustainable Development. Journalof Sustainable Development, 2(4), pp. 275-289.

iii. Epstein, M.J. \&Roy, M.J., 2001. Sustainability in Action: Identifying and Measuring the Key Performance Drivers. Long Range Planning, 34(5), pp. 585-604.

iv. Fandeli, C., 200o. Pengusahaan Ekowisata. Yogyakarta: FakultasKehutanan Universitas Gadjah Mada.

v. Fennel, D. A., 1999. Ecotourism: An Introduction. Routledge: London dan NewYork.

vi. $\quad$ Field, J., 2003. Social Capital. Routledge: London dan NewYork.

vii. Frooman, J., 2006. Stakeholders Influence Strategies. Academy of Management Review, 24(2), pp. 191-206

viii. Hudson, W. R., Haas, R.C. G. \& Uddin, W., 1997. Infrastructure Management. McGraw-Hill

ix. Ibrahim, L. D., 2006. Memanfaatkan Modal Sosial Komunitas Lokal Dalam Program Kepedulian Korporasi. Jurnal Filantropi dan Masyarakat Madani GALANG, 1(2).

x. Kleinrichert, D., 2008. Ethics, Power and Communities:Corporate Social Responsibility. Journal of Business Ethics, 78, pp. 475-485. doi:10.1007/s10551-006-9339-3

xi. Kutzner, D., Wright, A. A. \& Stark, A., 2009. Identifying Tourists' Preferences for Aboriginal Tourism Product Features: Implications for a Northern First Nation in British Columbia. Journal of Ecotourism, 8(2), pp. 99-114

xii. Narayan, D., 1999. Bonds and Bridges; Social Capital and Poverty. Washinton DC: World Bank.

xiii. $\quad$ Neuman, W. L., 2003. Social Research Methods: Qualitative and Quantitative Approaches. Pearson Education Inc. Boston

xiv. $\quad$ Ogujiuba, K. \& Jumare, F., 2012. Challenges of Economic Growth, Poverty and Development: Why Are the Millennium Development Goals (MDGs) not fair to Sub-Saharan Africa? Journal of Sustainable Development, 5(12), pp.52-64.

xv. Pitana, G.\& Gayatri, P. G., 2005. Sosiologi Pariwisata. Yogyakarta: ANDI.

xvi. $\quad$ Samodra, W., 1991. Pembangunan Berkelanjutan: Konsep dan Kasus. Yogyakarta: PT Tiara Wacana.

xvii. Sugiyono. 2009. Memahami Penelitian Kualitatif. Bandung: Penerbit Alfabeta.

xviii. $\quad$ United Nations. 2012. Millennium Development Goals (MDGs) Report. New York: United Nations. 